\title{
Conference Report: 'The Evangelical Prophet Isaiah Prophesied' (7 December 2018, Caltholic Theological Faculty, Charles University, Prague)
}

\author{
J A R O L A V B R O Ž
}

On December 7, 2018, an international biblical conference was held at the Catholic Theological Faculty on the textological, literary, and theological questions of the Book of the prophet Isaiah with the title 'The Evangelical Prophet Isaiah Prophesied' (Prorok evangelický Isaiáš prorokoval).

Among the distinct guests from abroad were Libor Marek, a lecturer at the Sacred Heart Major Seminary in Detroit (USA), and Peter Dubovský, a professor at the Pontifical Biblical Institute in Rome (Italy). L. Marek gave a presentation on 'Reception of Isaiah 7:17 in Qumran: The Use of Ambiguity of the Biblical Text,' in which he explained some approaches to the reception of the biblical text in the community of Qumran. In his keynote lecture 'Isaiah and Assyria', P. Dubovský discussed the historical context of the first part of Isaiah's book and the Assyrian politics of that time.

Other conference papers on the programme were by the biblical scholars from the Czech Republic. Július Pavelčík (Theological Faculty, University of South Bohemia, České Budějovice) spoke on 'Isaian Variations in the Letter of James'. The paper presented by Martin Prudký (Protestant Theological Faculty, Charles Unversity, Praha) focused on 'Poetic and Rhetorical Means in the Prophecy of Isaiah: An Example of Isa. 5:1-7'. The combination of linguistic, exegetical, and historical approach was introduced by Jaroslav Brož (Catholic Theological Faculty, Charles University, Prague) entitled 'Almāh and Parthenos in Isa. 7:14 and Matth. 1:23: The Case of J.L. Isenbiehl from Today's Perspective'. An example of early-modern Catholic exegesis was presented by Tomáš Matějec (Catholic Theological Faculty, Charles University, Prague) with his contribution 'As on the day of Midian: Typological Interpretation of Isa. 9:3 at Cornelius a Lapide'.

The conference also became an exceptional opportunity to present two recent translations of the Book of the prophet Isaiah into Czech. Gabriela Vlková and Jana Plátová (Sts Cyril and Methodius Faculty of Theology, Palacký University, Olomouc) presented their work in a series of commented translation of the Septuagint into Czech: Kniha Izajáš. Komentovaný preklad recké septuagitní verze, Praha: Vyšehrad, 2018. The second book presented was a new translation of Isaiah intended for liturgical use in the Roman Catholic Church, accompanied by an introduction and detailed exegetic notes written by Josef Hřebík, Jaroslav Brož (Catholic Theological Faculty, Charles University, Prague) and 
Pavel Jartym: Kniha proroka Izaiáše. Český katolický překlad, Praha: Česká biblická společnost, 2018. The conference could be held thanks to the support of the authorities of the Catholic Theological Faculty and sponsorship of the Czech Bible Society.

The conference was funded by the Charles University project PROGRES Q01 'Theology as a way of interpreting history, traditions and contemporary society'. doi: 10.14712/23363398.2020.13 